\title{
Human chorionic gonadotropin-dependent induction of an equine aldo-keto reductase (AKR1C23) with 20a-hydroxysteroid dehydrogenase activity during follicular luteinization in vivo
}

\author{
K A Brown, D Boerboom, N Bouchard, M Doré1, J G Lussier and J Sirois \\ Centre de Recherche en Reproduction Animale et Département de Biomédecine Vétérinaire, Faculté De Médecine Vétérinaire, Université de Montréal, 3200 Sicotte, \\ Saint-Hyacinthe, Québec, Canada J2S 7C6 \\ ${ }^{1}$ Département de Pathologie et Microbiologie, Faculté de Médecine Vétérinaire, Université de Montréal, Saint-Hyacinthe, Québec, Canada
}

(Requests for offprints should be addressed to J Sirois; E mail: jean.sirois@ umontreal.ca)

\begin{abstract}
Aldo-keto reductases (AKRs) are multifunctional enzymes capable of acting on a wide variety of substrates, including sex steroids. AKRs having $20 \alpha$-hydroxysteroid dehydrogenase $(20 \alpha-\mathrm{HSD})$ activity can reduce progesterone to

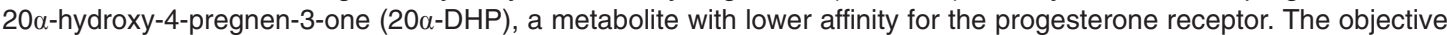
of this study was to investigate the regulation of equine AKR1C23 during human chorionic gonadotropin (hCG)-induced ovulation/luteinization. The equine AKR1C23 cDNA was cloned and shown to encode a 322 amino acid protein that is conserved (71-81\% identity) when compared with mammalian orthologs. RT-PCR/Southern blotting analyses were performed to study the regulation of AKR1C23 transcripts in equine preovulatory follicles isolated between 0 and $39 \mathrm{~h}$ after hCG treatment (ovulation occurring 39-42 h post-hCG). Results showed the presence of low AKR1C23 expression before hCG treatment, but a marked increase was observed in follicles obtained $12 \mathrm{~h}$ after hCG $(P<0.05)$. Analyses of isolated preparations of granulosa and theca interna cells identified low mRNA expression in both cell types prior to hCG treatment, with granulosa cells clearly being the predominant site of follicular AKR1C23 mRNA induction. A specific polyclonal antibody was raised against a fragment of the equine protein and immunoblotting analyses showed an increase in AKR1C23 protein in granulosa cell extracts when comparing follicles isolated at $36 \mathrm{~h}$ post-hCG vs those collected prior to treatment, in keeping with mRNA results. Immunohistochemical data confirmed the induction of the enzyme in follicular cells after hCG treatment. The enzyme was tested for $20 \alpha-H S D$ activity and was shown to exhibit a $K_{\mathrm{M}}$ of $3.12 \mu \mathrm{M}$, and a $\mathrm{V}_{\max }$ of $0.86 \mathrm{pmol} / \mathrm{min}$ per $10 \mu \mathrm{g}$ protein towards progesterone. The levels of $20 \alpha$-DHP measured in follicular fluid reflected this activity. Collectively, these results demonstrate for the first time that the gonadotropin-dependent induction of follicular luteinization is accompanied by an

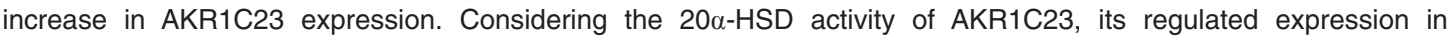
luteinizing preovulatory follicles may provide a biochemical basis for the increase in ovarian 20 $\alpha$-DHP observed during gonadotropin-induced luteinization/ovulation. (The nucleotide sequence reported in this paper has been submitted to GenBank with accession number AY955082.)
\end{abstract}

Journal of Molecular Endocrinology (2006) 36, 449-461

\section{Introduction}

Enzymes capable of performing oxidoreductase activities are widespread. One superfamily comprises the aldoketo reductases (AKRs), characterized as being monomeric, nicotinamide cofactor-dependent, cytosolic proteins of approximately 320 amino acids. These AKRs lack a Rossman-fold motif required by short-chain dehydrogenase/reductase family members for $\mathrm{NAD}(\mathrm{P}) \mathrm{H}$ binding (Wilson et al. 1992, 1995, Hoog et al. 1994, el-Kabbani et al. 1995, Jornvall et al. 1995). They are found in a wide variety of organisms, from bacteria to mammals, and metabolize a wide variety of substrates, including aliphatic and aromatic aldehydes, isoflavinoids, monosaccharides, steroids, prostaglandins (PGs) and polycyclic aromatic hydrocarbons. Fourteen families of AKRs are currently known (AKR1-14), encompassing over 100 proteins, with the AKR1 family being the largest and containing the aldehyde reductases, the aldose reductases, the hydroxysteroid dehydrogenases (HSDs) and the $5 \beta$-reductases. Isoforms of the AKR1C family have been demonstrated to share at least $84 \%$ amino acid sequence identity, and to exhibit $3 \alpha-, 17 \beta-$ and 20 $\alpha$-HSD activities (Penning et al. 2000). The current AKR1C3 has, in the past, also been named human liver $3 \alpha$-HSD type II, $17 \beta$-HSD type V, 
dihydrodiol dehydrogenase type $\mathrm{X}$ and $\mathrm{PG} \mathrm{F}{ }_{\alpha}$ synthase (PGFS), thereby contributing to the confusion regarding nomenclature (Penning et al. 1996).

AKRs having $20 \alpha$-HSD activity convert progesterone

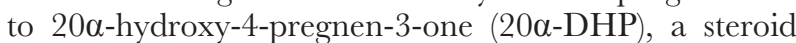
considered inactive due to its lower affinity for the progesterone receptor (PR) (Ogle \& Beyer 1982). However, levels of 20 $\alpha$-DHP have been demonstrated to increase after the coitus-induced preovulatory surge in luteinizing hormone $(\mathrm{LH})$ in the rabbit, as well as after human chorionic gonadotropin (hCG) treatment in both rats and rabbits and in cultured rat granulosa cells (Lau et al. 1978, Nordenstrom \& Johanson 1985, Lacy et al. 1993). Injection of equine chorionic gonadotropin (eCG) to immature rats with subsequent hGG treatment resulted in an increased production of progesterone and testosterone, as well as an increase in 20 $\alpha$-DHP levels surpassing those of progesterone prior to ovulation (Bauminger et al. 1977). 20 $\alpha$-DHP has been shown to induce ovulation when administered to immature rats after eCG treatment at doses 3 times that required by progesterone, an effect not seen with 20 $\alpha$-DHP's 5a-reduced metabolites (Gilles \& Karavolas 1981). 20a-DHP has also been shown to induce a positive feedback effect on LH serum concentrations in an estrogen-primed eugonadal woman (Leyendecker et al. 1976) and has been shown to prolong the preovulatory LH discharge in the rabbit (Hilliard et al. 1967). When monolayer cultures of rat pituitaries were exposed to $20 \alpha$-DHP, a negative feedback effect was observed on the basal secretion of follicle-stimulating hormone, whereas this progesterone metabolite increased the effect of gonadotropin-releasing hormone on LH secretion (Tang \& Spies 1975).

In mammals, follicular luteinization is triggered by a surge in LH released by the anterior pituitary. At this time, a vast number of biological and structural changes occur: the steroidogenic enzymes responsible for $17 \beta$-estradiol production are downregulated, whereas those contributing to progesterone synthesis, a steroid required for the establishment of pregnancy, are induced. The regulation of genes responsible for progesterone synthesis and action have been studied in great detail during the periovulatory period (Park \& Mayo 1991, Natraj \& Richards 1993, Sugawara et al. 1997, Boerboom \& Sirois 2001, Boerboom et al. 2003). However, no attempt has been made to study the regulation of proteins having progesterone-metabolizing activities, such as $20 \alpha-\mathrm{HSD}$, during the luteinization process. In the present study, the equine preovulatory follicle was used as a model to investigate the regulation of a novel AKR, AKR1C23, during hCG-induced ovulation/luteinization. The specific objectives were to clone equine AKR1C23 cDNA and determine the expression of its mRNA and protein in preovulatory follicles after hGG treatment.

\section{Materials and methods}

The nucleotide sequence reported in this paper has been submitted to GenBank with accession number AY955082.

\section{Materials}

The Prime-a-Gene labeling system, pGEM-T Easy Vector System I, and the Access RT-PCR system were purchased from Promega Corp. (Madison, WI, USA). The $\left[\alpha-{ }^{32} \mathrm{P}\right] \mathrm{dCTP}$ was purchased from PerkinElmer Canada, Inc. (Woodbridge, ON, Canada), and the QuickHyb hybridization solution was obtained from Stratagene Cloning Systems (La Jolla, CA, USA). The TRIzol total RNA isolation reagent, SuperScript II reverse transcriptase, $1 \mathrm{~kb}$ DNA ladder, synthetic oligonucleotides, 5'-rapid amplification of cDNA ends (RACE) system (Version 2·0), pcDNA3·1+ vector, and LipofectAMINE PLUS were purchased from Invitrogen Life Technologies (Burlington, ON, Canada). The Qiagen OneStep RT-PCR System, the pQE-30 vector and the Ni-NTA Superflow beads were obtained from Qiagen, Inc. (Mississauga, ON, Canada). The pGEX-2T vector, protease-deficient $E$. coli BL-21 and glutathione-Sepharose beads were obtained from Amersham Pharmacia Biotech (Baie d'Urfé, PQ Canada). The Expand High Fidelity DNA Polymerase was purchased from Roche Diagnostics (Laval, PQ, Canada). Biotrans nylon membranes (pore size, $0 \cdot 2 \mathrm{~mm}$ ) were obtained from ICN Pharmaceuticals, Inc. (Montréal, PQ Canada), and all electrophoretic reagents were purchased from Bio-Rad Laboratories (Richmond, CA, USA). The hCG was obtained from The Buttler Co. (Columbus, OH, USA). The Vectastain ABC kit was purchased from Vector Laboratories (Burlingame, CA, USA). The diaminobenzidine tetrahydrochloride, $\beta$-nicotinamide adenine dinucleotide phosphate (NADPH), and progesterone were purchased from Sigma Chemical Co. (St Louis, MO, USA).

\section{Cloning of the equine AKR1C23 cDNA}

The equine AKR1C23 transcript was isolated in fragments using a multistep cloning strategy (Fig. 1). A 402 bp RT-PGR product (Fig. 1Aa) was initially cloned from pooled equine ovarian RNA samples isolated from preovulatory follicles isolated before $(0 \mathrm{~h})$ and after $(36 \mathrm{~h})$ hCG treatment. Ovarian tissues were isolated and RNA was extracted as previously described (Kerban et al. 1999). RT-PCR was performed using the Access RT-PCR kit (Promega) as directed by the manufacturer, using $500 \mathrm{ng}$ RNA and oligonucleotide primers designed by sequence alignments of known AKR species homologs (Fig. 1B; primers 1 and 2). Following agarose gel electrophoresis, the RT-PCR product was excised 


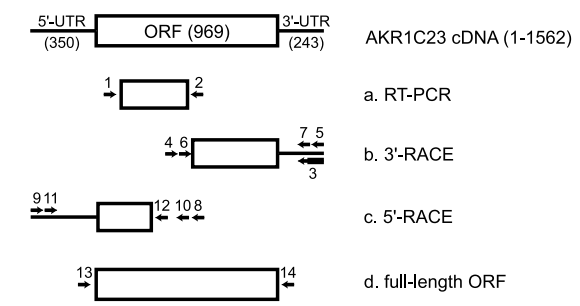

B

1. 5'-GGACTGGCCATCCGAAGCAAGAT-3'

2. 5'-CGGATGACATTCTACCTGGTTGCA-3'

3. 5'-GTACCGGATCCTCTAGAGAGCTCGTCGACCTCGAGG

' AATTCAAGCTTTTTTTTTTTTTTTTTTTT-3'

4. 5'-TGGGCTACTTCTCTTCGACTGC -3'

5. 5'-GTACCGGATCCTCTAGAGAGCTC-3'

6. 5'-CGGAGTGTCCAACTTTAACCGC-3'

7. 5'-GTCGACCTCGAGGAATTCAAGCTT-3'

8. 5'-CCCTGGCTTGACAGCCACAGG-3'

9. 5'-GGCCACGCGTCGACTAGTACGGGIIGGGIIGGGIIG-3'

10. 5'-GGCAGGCCGGACCAATTGCAG-3'

11. 5'-GGCCACGCGTCGACTAGTAC-3'

12. 5'-TGCAGTCGAAGAGAAGTAGCCCA-3'

13. 5'-GTGGGTACCGCCGCCACAATGGATCCCAAAGGTTGGC-3'

14. 5'-GGTCTCGAGTTAATAATCATCAGAAAATGGATACTCA-3'

Figure 1 Cloning of equine AKR1C23. (A) Cloned cDNA fragments. Each fragment is schematically represented, with its identity indicated on the right and its position in the deduced transcript sequence indicated in parentheses. Lines indicate untranslated regions (UTRs); open boxes designate the open reading frame (ORF). Lengths of the deduced transcript and its structural elements are indicated in bp. Arrows indicate the position and orientation of the oligonucleotides employed in the cloning processes, with numbers indicating their identity. (B) Oligonucleotides used in the various cloning procedures. Oligonucleotides 9 and 11 are components of the 5'-RACE kit (Invitrogen).

and ligated into the PGEM-T Easy plasmid vector (Promega), and proper recombinant plasmids were identified from transformed bacterial colonies using standard techniques (Sambrook et al. 1989). Sequencing of the insert was performed by the Service de Séquençage de l'Université Laval (Québec, PQ, Canada) using vector-based T7 and SP6 oligonucleotide primers. Sequences obtained from the initial RT-PCR product served as the basis for the design of specific oligonucleotides for $5^{\prime}$ - and $3^{\prime}$-RACE procedures. The $3^{\prime}$-RACE was performed as previously described (Boerboom et al. 2000), except 5 ug pooled ovarian tissue RNA (as described above) were used as a template for the initial RT reaction (Fig. 1Ab). Briefly, an RT reaction was performed using a poly-dT oligonucleotide with anchor sequences at its $5^{\prime}$ end (Fig. 1B; primer 3). This was followed by nested PCRs using oligonucleotide primers that bound to the anchor sequence in conjunction with AKR1C23-specific forward primers (Fig. 1B; primers 4-7). The product of the second PCR was isolated and sequenced as described above. 5'-RACE was performed using the 5'-RACE System, Version $2 \cdot 0$ kit (Invitrogen) as directed by the manufacturer, using $5 \mu \mathrm{g}$ pooled ovarian tissue RNA (as described above) and AKR1C23-specific primers for reverse transcription and PCR (Fig. 1B; primers 8, 10 and 12), along with forward primers supplied with the kit (Fig. 1B; primers 9 and 11). The longest product obtained (Fig. 1Ac) was isolated and sequenced as described above. A clone encompassing the entire coding region was isolated by RT-PCR (Fig. 1Ad), incorporating KpnI and XhoI restriction sites for subcloning into the eukaryotic expression vector pcDNA 3.1+ (Invitrogen), and found to correspond with the deduced primary AKR1C23 transcript reported herein (Fig. 1A). AKR1C23 nomenclature was attributed after the sequence was submitted to the AKR superfamily homepage (www.med.upenn.edu/akr) (Hyndman et al. 2003).

\section{Equine tissues and RNA extraction}

All animal procedures were approved by the institutional Animal Use and Care Committee.

Testicular tissues were obtained from the Large Animal Hospital of the Faculté de Médecine Vétérinaire (Université de Montréal) following a routine castration, whereas other non-ovarian tissues were collected at a local slaughterhouse.

Equine preovulatory follicles and corpora lutea were isolated at specific stages of the estrous cycle from Standardbred and Thoroughbred mares as previously described (Sirois \& Doré 1997). Briefly, when preovulatory follicles reached $35 \mathrm{~mm}$ in diameter during estrus, the ovulatory process was induced by injection of hCG (2500 IU, i.v.) and ovariectomies were performed via colpotomy using an ovariotome at $0,12,24,30,33,36$ or $39 \mathrm{~h}$ post-hCG ( $n=4-6 \mathrm{mares} / \mathrm{time}$ point; ovulation occurring 39-42 h post-hCG) (Sirois \& Doré 1997). Follicles were dissected into preparations of follicle wall (theca interna with attached granulosa cells) or further dissected into separate isolates of granulosa cells and theca interna. Ovariectomies were also performed on day 8 of the estrous cycle (day 0 , day of ovulation) to obtain corpora lutea ( $n=3$ mares) (Sirois \& Doré 1997).

Total RNA was isolated from tissues with TRIzol reagent (Invitrogen), according to manufacturer's instructions using a Kinematica PT 1200C Polytron Homogenizer (Fisher Scientific, Montréal, PQ Canada).

\section{Semi-quantitative RT-PCR and Southern analysis}

The Access RT-PCR System (Promega) was used for semi-quantitative analysis of AKR1C23 and ribosomal protein L7a (rpL7a) mRNA levels in equine tissues. Reactions were performed according to the manufacturer's directions, using sense (5'-GAAGCAACAAAC AATGGATCGC- $3^{\prime}$ ) and antisense (5'-CGACGTGG TTGCAGACAGGG-3') primers specific for equine AKR1C23, and sense (5'-ACAGGACATCGAGCGGA AACG-3') and antisense (5'-GGTCGTTTGTCTTCG GAGTTG-3') primers specific for the equine control 
gene rpL7a. These reactions resulted in the production of AKR1C23 and rpL7a DNA fragments of 587 and 516 bp respectively. Each reaction was performed using 100 ng total RNA, and cycling conditions were one cycle of $48{ }^{\circ} \mathrm{C}$ for $45 \mathrm{~min}$ and $94^{\circ} \mathrm{C}$ for $2 \mathrm{~min}$, followed by a variable number of cycles of $94^{\circ} \mathrm{C}$ for $30 \mathrm{~s}, 55^{\circ} \mathrm{C}$ for $1 \mathrm{~min}$ and $68{ }^{\circ} \mathrm{C}$ for $2 \mathrm{~min}$. The number of cycles used was optimized for each gene to fall within the linear range of PGR amplification and was 21 cycles for AKR1C23 and 18 cycles for rpL7a.

Following PCR amplification, samples were electrophoresed on 2\% TAE-agarose gels, transferred to nylon membranes, and hybridized with corresponding radiolabeled AKR1C23 and rpL7a cDNA fragments using Prime-a-Gene labeling system (Promega) and QuickHyb hybridization solution (Stratagene). Membranes were exposed to a phosphor screen, and signals were quantified on a Storm imaging system using the ImageQuant software version 1·1 (Molecular Dynamics, Amersham Biosciences, Sunnyvale, CA, USA).

\section{Production of an anti-equine AKR1C23 antibody}

A pair of sense (5'-GATGGATCGGATCGCAAAGGT TGGCGTGT- $3^{\prime}$ ) and antisense (5'-CAGAATTCGCG TGGGGTTAAAGTTGGACAC-3') primers that incorporated a BamHI and an EcoRI restriction site respectively were designed from the equine AKR1C23 open reading frame to generate a fragment $(\triangle \mathrm{AKR} 1 \mathrm{C} 23)$ spanning the region from $\mathrm{Asp}^{2}$ to $\mathrm{Arg}^{171}$. The fragment was amplified by PCR using the Expand High Fidelity polymerase (Roche Molecular Biochemicals) and following the manufacturer's protocol. The fragment was isolated after electrophoresis, digested with BamHI and EcoRI, subcloned into pGEX-2T in frame with the glutathione-S-transferase (GST) coding region (Amersham Pharmacia Biotech), and sequenced to confirm its identity. Protease-deficient E. coli BL-21 (Amersham Pharmacia Biotech) were transformed with the $\Delta \mathrm{AKR} 1 \mathrm{C} 23 / \mathrm{pGEX}-2 \mathrm{~T}$ construct, expression of the recombinant $\triangle \mathrm{AKR} 1 \mathrm{C} 23 / \mathrm{GST}$ fusion protein was induced with isopropyl-1-thio- $\beta$-Dgalactopyranoside (Fisher Scientific), and bacterial protein extracts were obtained after sonication and centrifugation. The $\triangle \mathrm{AKR} 1 \mathrm{C} 23 / \mathrm{GST}$ fusion protein was purified by affinity on glutathione-Sepharose beads (Amersham Pharmacia Biotech), digested with thrombin to release the $\triangle \mathrm{AKR} 1 \mathrm{C} 23$, resolved by one-dimensional SDS-PAGE, transferred to nitrocellulose, and stained with Ponceau S Red (Brûlé S et al. 2000). The $\Delta$ AKR1C23 band $\left(M_{\mathrm{r}}=19200\right)$ was cut and used to immunize rabbits as previously described (Brûlé et al. 2000).

To demonstrate the specificity of the AKR1C23 antibody, the coding region of the AKR1C23 was subcloned into the mammalian expression vector pcDNA3 $1+$ (Invitrogen) and transient transfections were performed using the HEK293 cell line as previously described (Filion et al. 2001). Briefly, HEK293 cells were seeded in $75 \mathrm{~cm}^{2}$ plates and transfected using $6 \mu \mathrm{g} / \mathrm{plate}$ of AKR1C23/pcDNA3.1 constructs and $36 \mu \mathrm{g}$ LipofectAMINE PLUS in $1.7 \mathrm{ml}$ MEM, in accordance with the manufacturer's protocol. Three hours after transfection, cells were incubated in fresh culture media for $24 \mathrm{~h}$, collected, and protein extracted and analyzed by immunoblotting.

\section{Cell extracts and immunoblotting analysis}

Ovarian cell extracts were prepared as previously described (Filion et al. 2001). Briefly, tissues were homogenized and sonicated on ice in $20 \mathrm{mM}$ Tris $(\mathrm{pH}$ $8 \cdot 0), 50 \mathrm{mM}$ EDTA and $0.1 \mathrm{mM}$ diethyldithiocarbamic acid buffer containing $1.0 \%$ Tween. The sonicates were centrifuged at $16000 \boldsymbol{g}$ for $15 \mathrm{~min}$ at $4{ }^{\circ} \mathrm{C}$. The recovered supernatant (whole cell extract) was stored at $-80{ }^{\circ} \mathrm{C}$ until electrophoretic analyses were performed. Protein concentration was determined by the method of Bradford (1976) (Bio-Rad protein assay). Samples (50 $\mu \mathrm{g}$ protein) were resolved by one-dimensional SDS-PAGE and electrophoretically transferred to polyvinylidene difluoride membranes (Filion et al. 2001). Membranes were incubated with the polyclonal anti-AKR1C23 antibody (1:4000), and immunoreactive proteins were visualized on Kodak X-OMAT AR film (Eastman Kodak Co., Rochester, NY, USA) after incubation with the horseradish peroxidase-linked donkey antirabbit secondary antibody (1:10000 dilution) and the enhanced chemiluminescence system (ECL Plus), following the manufacturer's protocol (Amersham Pharmacia Biotech).

\section{Immunohistochemical localization of AKR1C23}

Immunohistochemical staining was performed using the Vectastain ABC kit (Vector Laboratories), as previously described (Sirois \& Doré 1997). Briefly, formalin-fixed tissues were paraffin-embedded, and $3 \mu \mathrm{m}$-thick sections were prepared and deparaffined through a graded alcohol series. Endogenous peroxidase was quenched by incubating the slides in $0.3 \%$ hydrogen peroxide in methanol for $30 \mathrm{~min}$. After rinsing in PBS for $15 \mathrm{~min}$, sections were incubated with diluted normal goat serum for $20 \mathrm{~min}$ at room temperature. The anti-AKR1C23 antibody was diluted in PBS (1:1000 dilution) and applied, and sections were incubated overnight at $4{ }^{\circ} \mathrm{C}$. Control sections were incubated with PBS. After rinsing in PBS for $10 \mathrm{~min}$, a biotinylated goat anti-rabbit antibody (1:222 dilution; Vector Laboratories) was applied, and sections were incubated for $45 \mathrm{~min}$ at room 
temperature. Sections were washed in PBS for $10 \mathrm{~min}$ and incubated with avidin DH-biotinylated horseradish peroxidase $\mathrm{H}$ reagents (Vectastain $\mathrm{ABC}$ kit) for $45 \mathrm{~min}$ at room temperature. After washing with PBS for $10 \mathrm{~min}$, the reaction was revealed using diaminobenzidine tetrahydrochloride as the chromogen. Sections were counterstained with Gill's hematoxylin stain and mounted.

\section{AKR1C23 expression, in vitro enzyme activity and measurement of $20 \alpha$-DHP concentration in follicular fluid}

A pair of sense (5'-CTCGGTACGATGGATCGCAAA GGTTGGGGT-3') and antisense (5'-TGGGTGGAG TTAATAATCATCAGAAAATGG-3') primers that incorporated a KpnI and a PstI restriction site respectively were designed from the equine AKR1C23 open reading frame to generate a full-length AKR1C23 protein. The cDNA was amplified by PCR using the Expand High Fidelity polymerase (Roche Molecular Biochemicals) and following the manufacturer's protocol. The fragment was isolated after electrophoresis, digested with KpnI and PstI, subcloned into pQE-30 in frame with the His-tag coding region (Qiagen), and sequenced to confirm its identity.

E. coli M15 (Qiagen) were transformed with the AKR1C23/pQE-30 construct, expression of the His-tagged AKR1C23 fusion protein was induced with $1 \mathrm{mM}$ isopropyl-1-thio- $\beta$-D-galactopyranoside (Fisher Scientific), and bacterial protein extracts were obtained after lysis and centrifugation according to the manufacturer's recommendations.

The His-AKR1C23 fusion protein was purified by affinity on Ni-NTA resin (Qiagen), and concentrated using a $30 \mathrm{kDa}$ cutoff Amicon centrifugal filter device (Millipore Corp.).

The 20a-HSD activity was examined by following the decrease in NADPH absorbance at $340 \mathrm{~nm}$ on a Beckman Coulter DU800 spectrophotometer (Madore et al. 2003). Ten micrograms of purified AKR1C23 protein were assayed at $37^{\circ} \mathrm{C}$ in $50 \mathrm{mM}$ Tris- $\mathrm{HCl}(\mathrm{pH}$ $7 \cdot 5)$ with saturating $\mathrm{NADPH}(100 \mu \mathrm{M})$ at various progesterone concentrations.

The follicular fluid present in equine preovulatory follicles isolated between 0 and $39 \mathrm{~h}$ post-hCG was analyzed for $20 \alpha$-DHP content by a gas chromatographic mass spectrometric (GC/MS) method developed to measure steroid hormone levels in rat and monkey serum (Bérubé et al. 2000). Briefly, 20 $\alpha$-DHP was extracted from follicular fluid by liquid-liquid and solid-phase extraction. Derivatization reactions were performed to improve the chromatographic and detection response of the steroids. Unconjugated steroids were quantified by means of GC/MS, using chemical ionization.

\section{Statistical analysis}

One-way ANOVA was used to test the effect of time after hCG administration on levels of AKR1C23 mRNA and on 20 $\alpha$-DHP concentration. AKR1C23 mRNA levels were normalized with the control gene rpL7a before analysis. When ANOVAs indicated significant differences $(P<0 \cdot 05)$, Dunnett's test was used for multiple comparisons of individual means $(P<0 \cdot 05)$. Statistical analyses were performed using JMP software (SAS Institute, Inc., Cary, NC, USA).

\section{Results}

\section{Characterization of equine AKR1C23}

To clone the equine AKR1C23 transcript, RT-PCR was performed on ovarian RNA using oligonucleotide primers designed by sequence alignment of known AKR1C species homologs. The resulting cDNA fragment (Fig. 1Aa) was sequenced and found to be highly homologous to $20 \alpha$-HSD transcripts identified thus far. A combination of 5'- and 3'-RACE reactions yielded cDNA products corresponding to all remaining coding regions, as well as $3^{\prime}$ - and $5^{\prime}$-untranslated regions (Fig. $1 \mathrm{Ab}$ and Ac). A RT-PCR product was generated to extend the length of the open reading frame, thereby confirming that all three products were derived from the same transcript (Fig. 1Ae). The deduced $1562 \mathrm{bp}$ primary transcript encoded a $969 \mathrm{bp}$ open reading frame (Fig. 1A, GenBank accession number AY955082), which predicted a protein of 322 amino acid residues.

The predicted protein is highly conserved, with a single amino acid deletion, when compared with human (AKR1C1) (Blouin et al. 2005), macaque (AKR1C1) (Higaki et al. 2002), rabbit (AKR1C5) (Lacy et al. 1993), cow (Madore et al. 2003) and rat (AKR1C8) (Albarracin

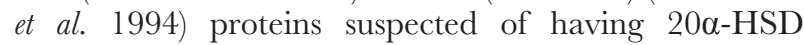
activity. The equine AKR1C23 has $80.8 \%$ identity at the amino acid level and a $85 \cdot 3 \%$ identity at the nucleic acid level when compared with human AKR1G1 (Fig. 2). All putative conserved amino acids implicated in AKR1C function appear to be present in the equine enzyme (Fig. 2).

\section{Tissue distribution of equine AKR1C23 mRNA}

To study the tissue distribution of equine AKR1C23, various equine tissues were obtained and the expression of AKR1C23 was examined by RT-PCR/Southern blotting. Results showed that the AKR1C23 transcript was expressed in many of the tissues studied (Fig. 3A). Levels of AKR1C23 mRNA were highest in a preovulatory follicle isolated $36 \mathrm{~h}$ after hCG (i.e. approximately $3-6 \mathrm{~h}$ before ovulation) and testis; moderate in liver, skeletal muscle, heart, kidney and 

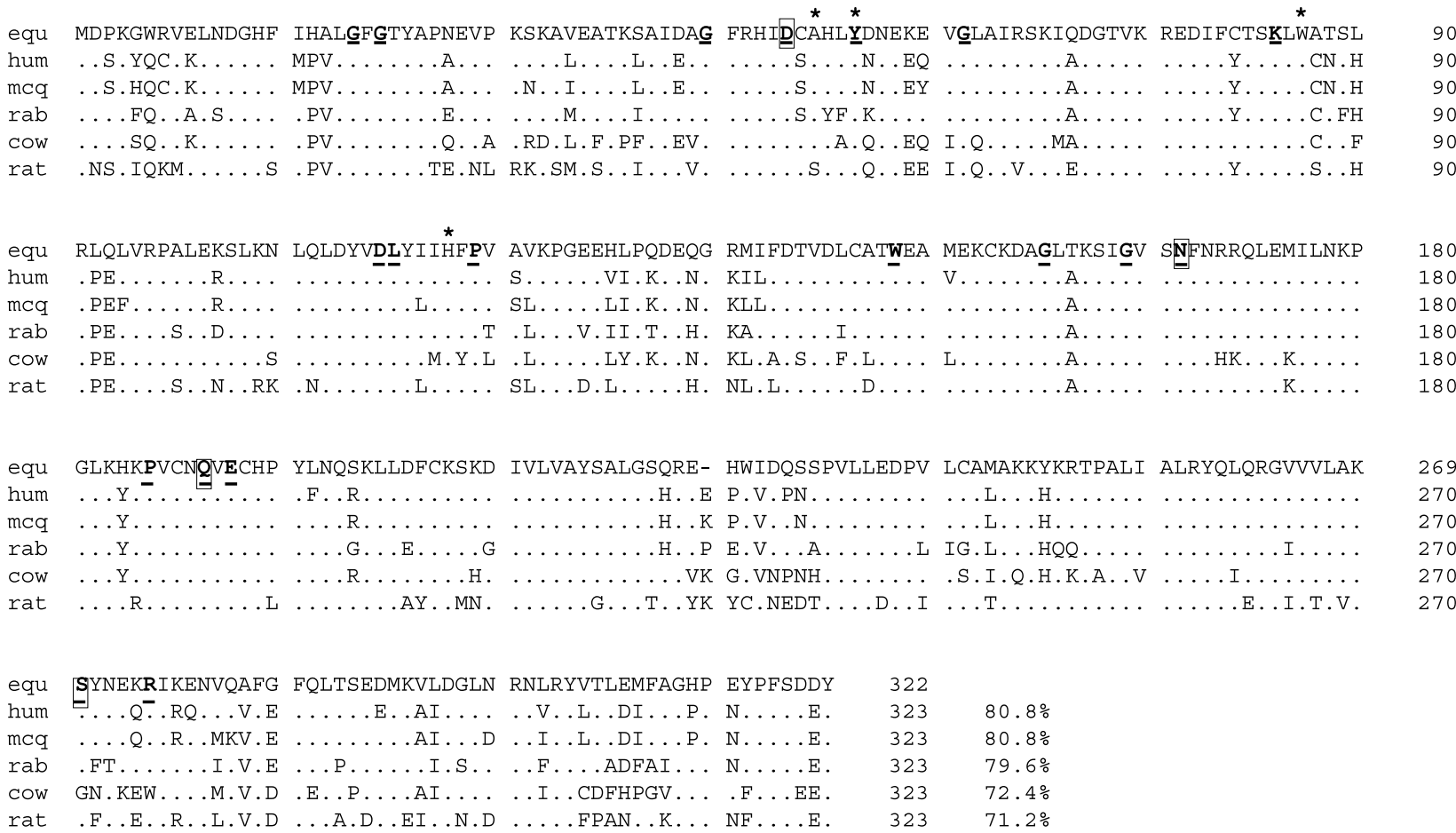

Figure 2 Deduced primary structure of the equine AKR1C23 protein and comparison with known 20 $\alpha$-HSDs and bovine PGFS. The predicted amino acid sequence of the equine (equ) AKR1C23 protein is aligned with human (hum; AKR1C1; GenBank accession number NP_001344), macaque (mcq; AKR1C1; Q95JH7), rabbit (rab; AKR1C5; P80508), and rat (AKR1C8; NP_612519) 20 $\alpha$-HSDs, as well as cow PGFS-like2 (cow; N/A; AAN11329). Identical residues are indicated by a printed period, numbers on the right refer to the last amino acid residue on that line. Bold underlined residues are highly conserved among AKRs, boxed residues are thought to be involved in NADPH cofactor binding, and residues with an asterisk are involved in substrate binding (Jez et al. 1997).

lung; low in brain, stomach and uterus; and very low in thymus, adrenal, spleen and skin. However, levels of the control gene rpL7a remained relatively constant in all tissues studied (Fig. 3B).

\section{Regulation of AKR1C23 transcript in preovulatory follicles and corpora lutea}

The regulation of AKR1C23 mRNA in preovulatory follicles was studied by RT-PGR/Southern blotting, using follicles isolated during estrus at $0,12,24$ and $36 \mathrm{~h}$ after the administration of an ovulatory dose of hCG. Total RNA was extracted from the follicle wall (theca interna with attached granulosa cells), as well as from three corpora lutea obtained on day 8 of the estrous cycle. Levels of equine AKR1C23 mRNA were low in equine preovulatory follicles prior to treatment with hCG $(0 \mathrm{~h})$, but were clearly induced from $12 \mathrm{~h}$ to $36 \mathrm{~h}$ post-hCG (Fig. 4A). The AKR1C23 mRNA expression returned to basal levels in the corpus luteum at day 8 of the cycle (Fig. 4A). When results from multiple follicles and corpora lutea were expressed as ratios of AKR1C23 to rpL7a, a significant increase in AKR1C23 transcript

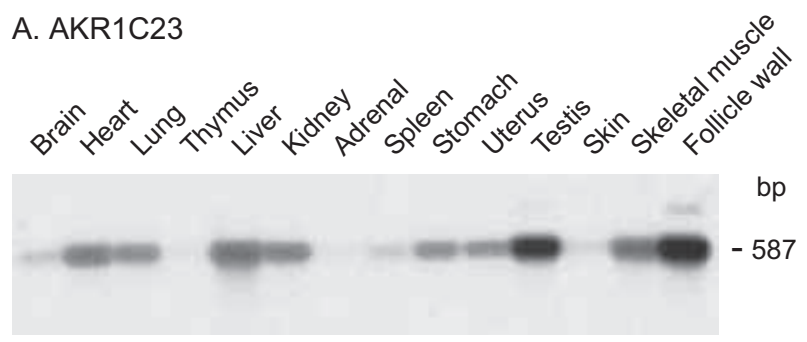

B. $r p L 7 a$

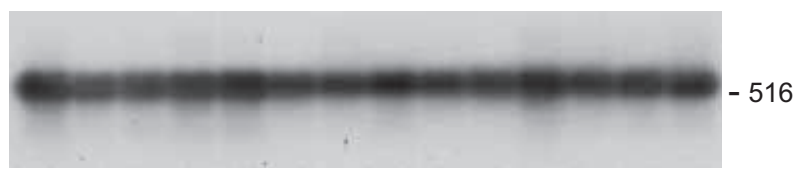

Figure 3 Expression of AKR1C23 mRNA in equine tissues. Total RNA was extracted from various equine tissues, and samples (100 ng) were analyzed for AKR1C23 and rpL7a (control gene) content by a semi-quantitative RT-PCR/Southern blotting techniques, as described in Materials and methods.

(A) Expression of AKR1C23 mRNA in equine tissues.

(B) Expression of rpL7a mRNA in equine tissues. The number of PCR cycles for each gene was within the linear range of amplification, and they represented 21 and 18 cycles for AKR1C23 and rpL7a respectively. Numbers on the right indicate the size of the PCR fragment. 


\section{A. AKR1C23}

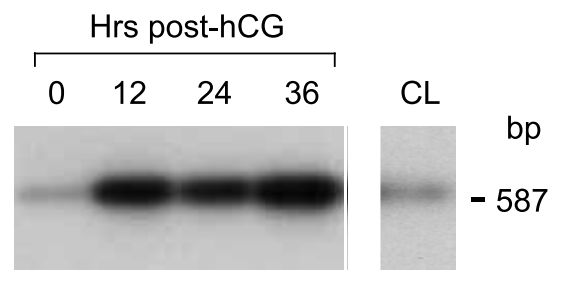

B. $r p L 7 a$

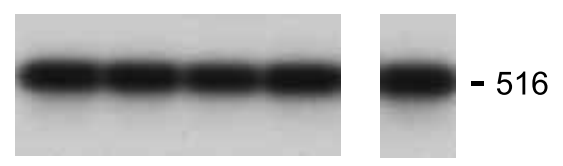

C.

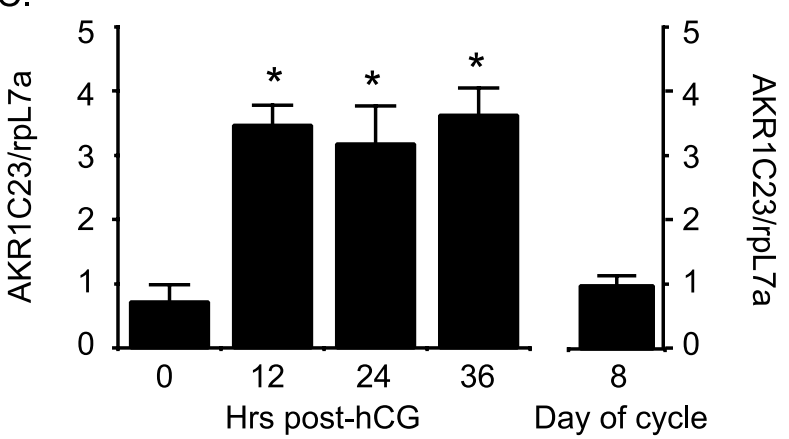

Figure 4 Regulation of AKR1C23 transcript by hCG in equine preovulatory follicles. Preparations of follicle wall were obtained from preovulatory follicles isolated between 0 and $36 \mathrm{~h}$ after hCG, and corpora lutea (CL) were isolated on day 8 of the estrous cycle. Samples (100 ng) of total RNA were analyzed for AKR1C23 and rpL7a content by a semi-quantitative RT-PCR/Southern blotting technique, as described in Materials and methods. (A) Regulation of AKR1C23 mRNA in equine follicles (one representative follicle per time point).

(B) Constitutive expression of rpL7a mRNA in the same follicles. Numbers on the right indicate the size of the PCR fragment. (C) Relative levels of intensity of AKR1C23 signal, normalized to the control gene rpL7a (mean \pm S.E.M. $n=5$ or 6 distinct follicles (i.e. mares) per time point and $n=3$ different corpora lutea). Bars marked with an asterisk are significantly different from $0 \mathrm{~h}$ post-hCG $(P<0.05)$.

was detected in follicles, reaching a plateau from 12 to $36 \mathrm{~h}$ post-hCG $(P<0 \cdot 05$; Fig. $4 \mathrm{C})$. No change in rpL7a transcript was detected after gonadotropin treatment (Fig. 4B).

In order to determine which cell type in the equine follicle wall was responsible for the expression of the AKR1C23 transcript, granulosa and theca interna cells were isolated from follicles obtained between 0 and $39 \mathrm{~h}$ post-hCG (Fig. 5). Results indicated that granulosa cells were the predominant site of AKR1C23 expression and that this cell type contributed more importantly to the increase in transcript observed in intact follicle wall preparations. In granulosa cells, this increase was significant between 12 and $39 \mathrm{~h}$ post-hCG $(P<0 \cdot 05$; Fig. 5A). Results demonstrated a slight yet significant induction of AKR1C23 mRNA in theca interna cells at $39 \mathrm{~h}$ post-hCG $(P<0 \cdot 05$; Fig. $5 \mathrm{~B})$.

\section{Expression of AKR1C23 protein in equine preovulatory follicles}

The hCG-dependent induction of AKR1C23 was studied at the protein level by immunoblotting and immunohistochemistry in follicles at 0 and 36 or $39 \mathrm{~h}$ post-hCG. The specificity of the antibody was confirmed, as it recognized the equine AKR1C23 protein overexpressed in HEK293 cells $\left(M_{\mathrm{r}}=37000\right.$; Fig. 6A). Immunoblotting analyses were performed on protein extracts from granulosa cells and theca interna at 0 and $36 \mathrm{~h}$ post-hCG. An increase in levels of immunoreactive AKR1C23 was observed at $36 \mathrm{~h}$ post-hCG in granulosa cells (Fig. 6B). However, little or no signal was detected in theca interna samples (Fig. 6C). Immunohistochemical results demonstrated a marked change in AKR1C23 staining after hCG treatment (Fig. 7). Follicles isolated prior to hCG treatment $(0 \mathrm{~h})$ show a very compact granulosa cell layer and light staining (Fig. 7A). Although some darker staining is apparent in the periantral granulosa cells, this is probably due to the 'edge effect' observed when using this technique (Fig. 7A). The administration of hCG caused the granulosa cell layer to expand and an increase in AKR1C23 accumulation (Fig. 7B-D) was observed in follicles isolated $39 \mathrm{~h}$ post-hCG. Control sections of follicles isolated at $39 \mathrm{~h}$ post-hCG showed no staining when AKR1C23 antibody was omitted (Fig. 7F). The pattern of expression in testes demonstrated AKR1C23 expression in Leydig cells only (Fig. 7E).

\section{$20 \alpha$-HSD activity and concentration of $20 \alpha-$ DHP in follicular fluid}

The AKR1C23 recombinant protein was overexpressed in $E$. coli M15 cells and affinity-purified using an Ni-NTA column. Activity assays were done by monitoring the absorbance at $340 \mathrm{~nm}$, at a temperature of $37^{\circ} \mathrm{C}$, and values were corrected for the background signal in the absence of substrate. Enzyme functionality was confirmed via its ability to reduce phenanthrenequinone (data not shown). The use of various concentrations of progesterone established the 20 $\alpha$-HSD activity of the AKR1C23 enzyme. The LineweaverBurke plot for AKR1C23 reflected a $K_{\mathrm{M}}$ of $3 \cdot 12 \mu \mathrm{M}$ and a $\mathrm{V}_{\max }$ of $0.86 \mathrm{pmol} / \mathrm{min}$ per $10 \mu \mathrm{g}$ protein towards progesterone (Fig. 8A). When follicular fluid was examined, a significant increase in 20a-DHP was observed 30-36 h post-hCG (Fig. 8B). 


\section{A. Granulosa cells}
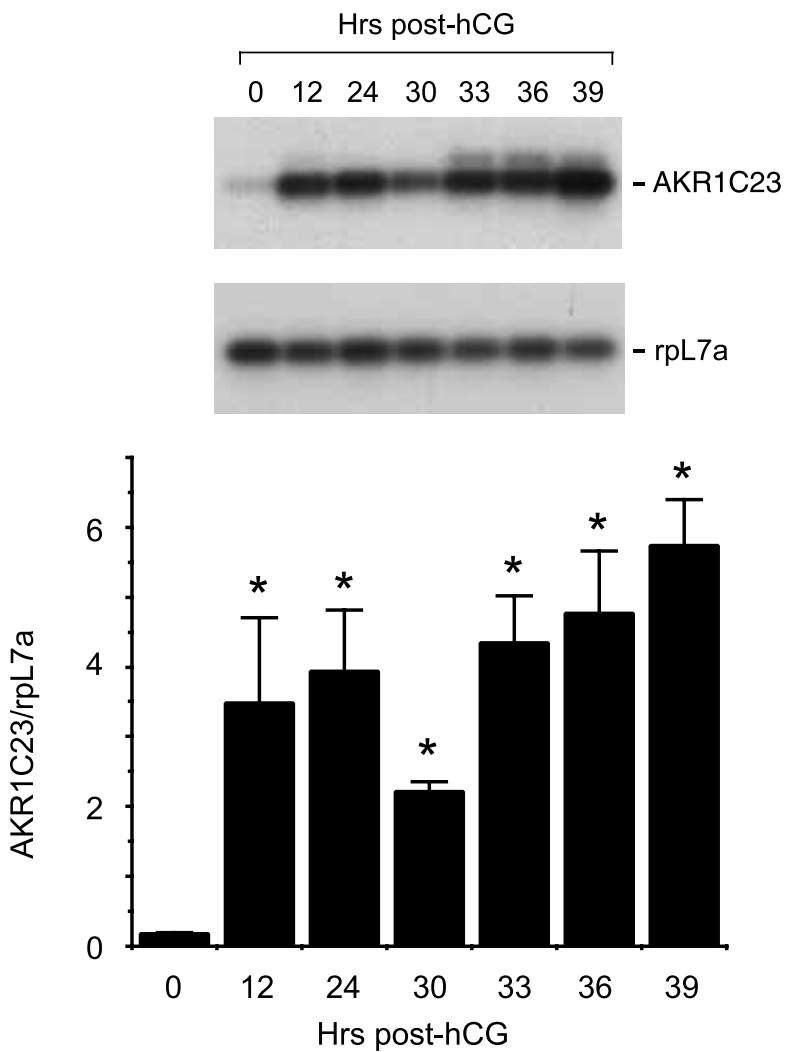

\section{B. Theca interna}
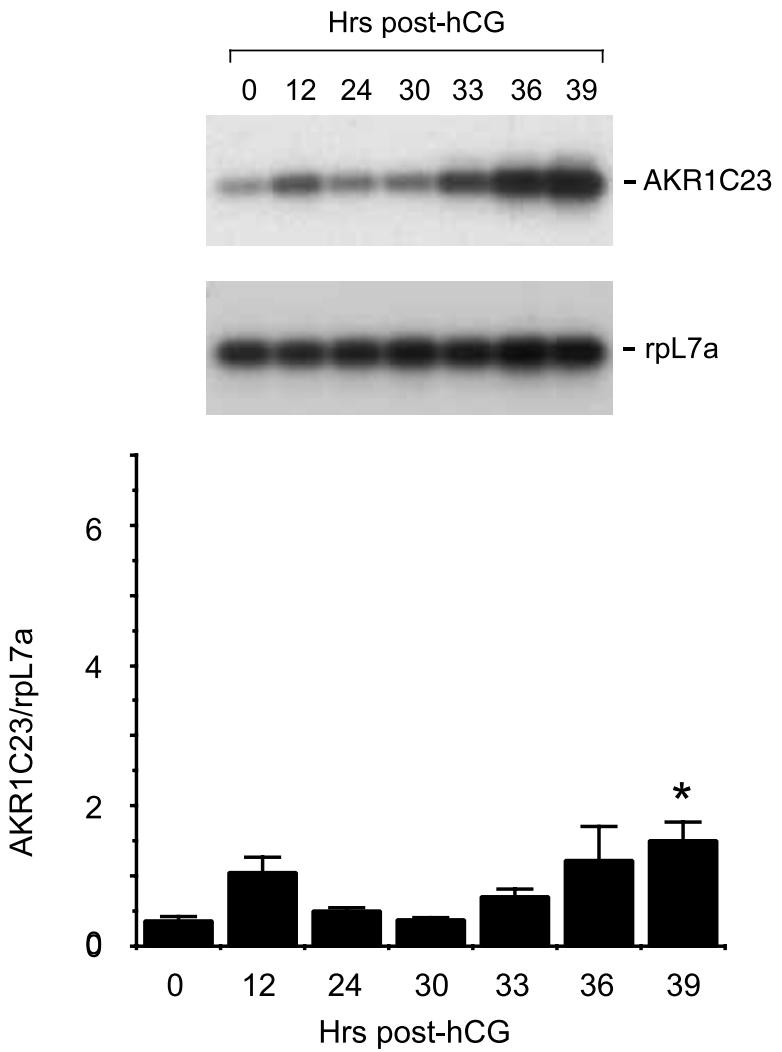

Figure 5 Regulation of AKR1C23 mRNA in equine granulosa and theca interna cells. Preparations of granulosa cells (A) and theca interna (B) were isolated from equine preovulatory follicles between 0 and $39 \mathrm{~h}$ after hCG treatment, and samples (100 ng) of total RNA were analyzed for AKR1C23 and rpL7a content by a semi-quantitative RT-PCR/Southern blotting technique, as described in Materials and methods. The AKR1C23 signal was normalized with the control gene rpL7a, and results are presented as a ratio of AKR1C23 to rpL7a (means \pm S.E.M.; $n=4$ samples (i.e. mares) per time point). Bars marked with an asterisk are significantly different from $0 \mathrm{~h}$ post-hCG $(P<0.05)$. Insets show representative results for AKR1C23 and rpL7a mRNA levels from one sample per time point.

\section{Discussion}

This study demonstrates for the first time that the process of follicular luteinization induced by $\mathrm{hCG}$ is accompanied by an increase in expression of AKR1C23, an AKR with many potential activities, including the conversion of progesterone to 20 $\alpha$-DHP. The process of luteinization/ovulation has previously been associated with dramatic changes in levels of steroidogenic enzymes in the different cellular compartments of the preovulatory follicle. Notably, a marked decrease or loss in the cytochrome P450 17 $\alpha$-hydroxylase/17,20-lyase and aromatase, which are key enzymes involved in androgen and estrogen biosynthesis, and the increase in steroidogenic acute regulatory protein and cytochrome $\mathrm{P} 450$ cholesterol side-chain cleavage expression, which contribute to enhanced progesterone synthesis (Fortune 1994, Richards 1994, Ronen-Fuhrmann et al. 1998, Sandhoff et al. 1998). Such changes have also been observed during hCG-induced luteinization/ovulation in the mare (Boerboom et al. 1999, Kerban et al. 1999, Boerboom \& Sirois 2001). However, there has been no

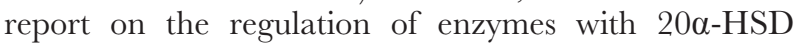
activity during the periovulatory period. Previous investigations of the expression of $20 \alpha-H S D$ in the ovary have primarily been limited to the examination of its regulation during luteolysis prior to parturition by Northern blotting analysis and by tissue distribution analyses by in situ hybridization (Albarracin et al. 1994, Nishizawa et al. 2000, Pelletier et al. 2003). Collectively, these studies revealed that the 20a-HSD gene (AKR1C8) was highly expressed in the rat corpus luteum at the end of gestation, and that the human $20 \alpha$-HSD (AKRlC1) promoter was functional in porcine luteinized granulosa cells in culture.

Results from the present study suggest that the induction of a progesterone-metabolizing enzyme such as AKR1C23 may provide the biochemical basis for the 
A.

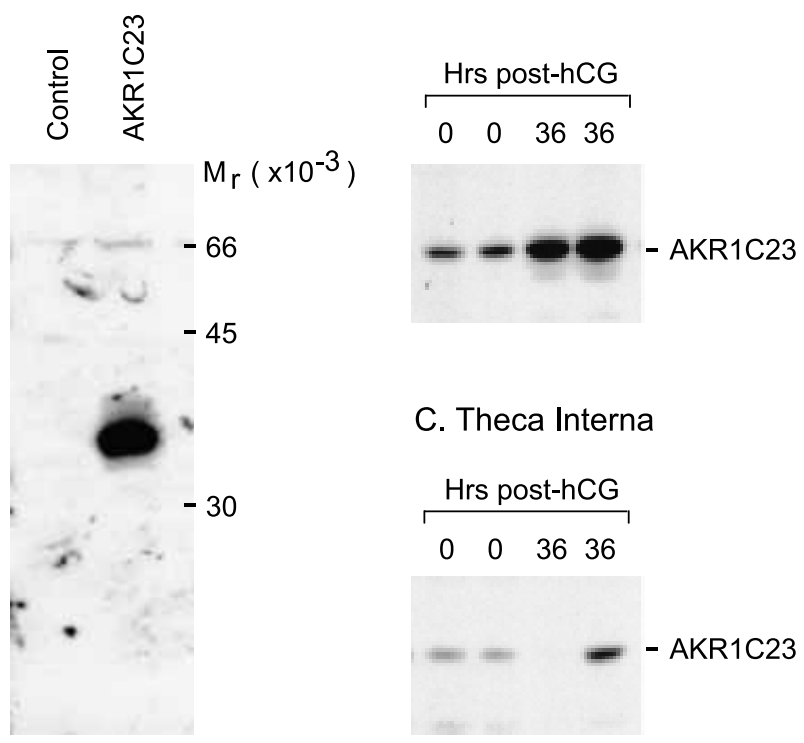

Figure 6 AKR1C23 primary antibody specificity and regulation of AKR1C23 protein by hCG in equine granulosa and theca interna. Protein extracts were prepared from transiently transfected and mock-transfected (control) HEK293 cells (A), as well as from granulosa cells $(B)$ and theca interna (C) isolated 0 and $36 \mathrm{~h}$ after hCG treatment ( $n=2$ samples (i.e. mares) per time point) and were analyzed by one-dimensional SDS-PAGE and immunoblotting using a specific polyclonal antibody raised against a fragment of the equine AKR1C23 protein, as described in Materials and methods. Results from protein extracts $(50 \mu \mathrm{g} / \mathrm{lane})$ are shown. Markers on the right indicate the migration of the molecular weight $\left(M_{\mathrm{r}}\right)$ standards (A) and expected position of AKR1C23 protein (B and C).

increase in 20 $\alpha$-DHP observed during the periovulatory

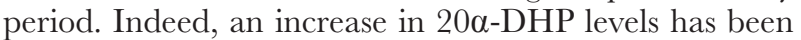
demonstrated to occur in a number of species, including the rat and rabbit (Lau et al. 1978, Nordenstrom \& Johanson 1985, Lacy et al. 1993). This study establishes that such an increase in $20 \alpha$-DHP also occurs in mares. However, the precise role of AKR1C23 during follicular luteinization/ovulation is intriguing and remains to be investigated. Its purpose as a progesterone-metabolizing enzyme remains perplexing since progesterone appears to be required for ovulation, as demonstrated by the anovulatory phenotype of PR-mutant mice (Lydon et al. 1995). AKR1C23's physiological importance may involve its ability to produce $20 \alpha-\mathrm{DHP}$. This metabolite has been shown to promote ovulation and gonadotropin secretion, and has been shown to increase sexual receptivity when metabolized further by $5 \alpha$-reductase in the brain (Frye \& Leadbetter 1994).

The multifunctional nature of the AKR protein led investigators to question the predominant role of the enzyme under physiological conditions. However, the difficulties involved in substrate manipulation, product analysis and enzyme stability, make it hard to have a comparative view of all possible AKR activities under similar conditions. In this study, we demonstrate that the AKR1C23 enzyme does convert progesterone to 20a-DHP with an affinity that approaches that previously reported for the human enzyme (Zhang et al. 2000). AKRs of this type, like AKR1C3 and AKR1C7, have also been shown to harbor PGFS-like activity, where this enzyme converts $\mathrm{PGD}_{2}$ into $9 \alpha, 11 \beta \mathrm{PGF}_{2}$, a $\mathrm{PGF}_{2 \alpha}$ isomer, as well as converting $\mathrm{PGH}_{2}$ into $\mathrm{PGF}_{2 \alpha}$ (Watanabe et al. 1986, Desmond et al. 2003). Considering that the levels of $\mathrm{PGF}_{2 \alpha}$ have been demonstrated to increase following hCG treatment in equine preovulatory follicles (Sirois \& Doré 1997), it is not unreasonable to think that AKR1C23 may contribute to this increase in $\mathrm{PGF}_{2 \alpha}$. The concept of a protein having many enzymatic activities working in concert has previously been described (Madore et al. 2003), where an aldose reductase (AKR1B5) was shown to have both $20 \alpha$-HSD and PGFS activities in cultures of bovine uterine endometrial cells. It was speculated that these concerted activities may lead to termination of the estrous cycle (Madore et al. 2003). Other possible activities of

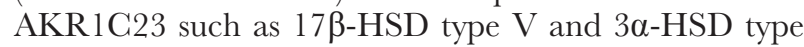
II, which convert androstenedione to testosterone and $5 \alpha$-dihydrotestosterone to androstanediol respectively have yet to be examined and their role, if any, during follicular luteinization needs to be elucidated.

The molecular control of AKR IC expression remains largely uncharacterized. Moreover, because of confusion regarding nomenclature, difficulties lie in identifying precisely which AKR was being studied in previous publications. Many reports addressed the regulation of AKRs speculated to have $20 \alpha$-HSD activity in various tissues, including the ovary (Strauss \& Stambaugh 1974, Lacy et al. 1993, Albarracin et al. 1994, Stocco et al. 2000, Pelletier et al. 2003). However, most ovarian studies remained largely at the level of the corpus luteum. Early investigations on the luteolytic effects of $\mathrm{PGF}_{2 \alpha}$ showed that $20 \alpha-H S D$ activity is induced 150 -fold in the rat ovary (Strauss \& Stambaugh 1974), this being consistent with more recent findings that demonstrate that rat 20a-HSD (AKR1C8) is induced by $\mathrm{PGF}_{2 \alpha}$ (Stocco et al. 2000). The transcription factor Nur 77 was shown to play a key role in the $\mathrm{PGF}_{2 \alpha}$-dependent induction of 20 $\alpha$-HSD (AKR1C8) in rat luteal cells (Stocco et al. 2000). The present study identifies high/ovulatory levels of gonadotropins as a physiological regulator of AKR1C23 in the preovulatory follicle, with the predominant regulation observed in granulosa cells. Interestingly, LH has previously been shown to upregulate Nur77 in rat granulosa cells (Park et al. 2003), thus providing a potential trans-activating factor for follicular AKR1C23 gene expression. Conversely, previous investigations suggest that prolactin is a repressor of $20 \alpha$-HSD expression, since it was shown to 

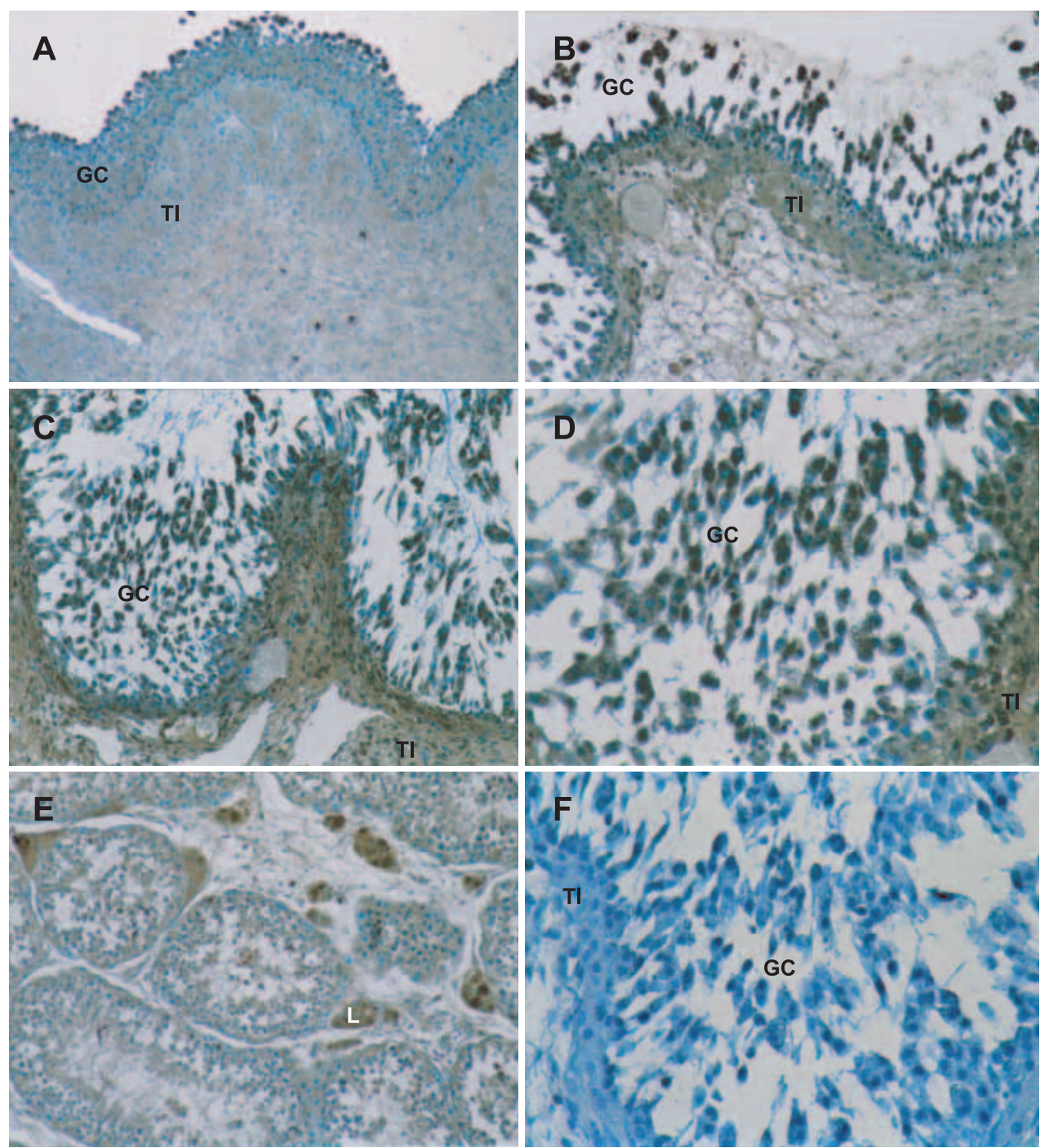

Figure 7 Immunohistochemical localization of AKR1C23 in equine preovulatory follicles.

Immunohistochemistry was performed on formalin-fixed sections of preovulatory follicles isolated at 0 and $39 \mathrm{~h}$ after hCG treatment and of equine testicular tissues, as described in Materials and methods. Results show relatively weak, but detectable, AKR1C23 staining in granulosa (GC) and theca interna ( $\mathrm{TI})$ cells of a preovulatory follicle obtained $0 \mathrm{~h}$ after $\mathrm{hCG}$ administration $(\mathrm{A})$, but a marked increase in signal intensity in both cell types of distinct follicles isolated $39 \mathrm{~h}$ after hCG treatment (B-D). (E) Intense AKR1C23 immunoreactivity is observed in Leydig (L) cells of equine testicular sections. (F) Control staining from the follicular tissue presented in (D) was negative when the primary antibody was omitted. Magnification, $\times 200$ (A-C and E) and $\times 400$ (D and F).

reduce the 20 $\alpha$-HSD (AKR1C8) protein level during corpus luteum regression in vivo, and in rat luteal cells in vitro (Albarracin et al. 1994).

In summary, this study is the first to characterize the primary structure of AKR1C23, to investigate the expression of the AKR1C23 gene in a developmental series of preovulatory follicles, and to identify ovulatory levels of gonadotropins as a positive regulator of AKR1C23 expression. The deduced primary structure of AKR1C23 is highly conserved when compared with species homologs with all putative conserved amino acids implicated in NADPH and substrate binding present (Jez et al. 1997). Although the precise molecular control of AKR1C23 induction in preovulatory follicles remains to be elucidated, it is interesting to note that the luteinization/ovulatory process is accompanied by an induction of $\mathrm{PGF}_{2 \alpha}$ and Nur77 (Sirois \& Doré 1997, Park et al. 2003). Given their putative role in 20 $\alpha$-HSD expression (Strauss \& Stambaugh 1974, Stocco et al. 2000), it will be interesting to determine whether they 


\section{A. Lineweaver-Burk plot}

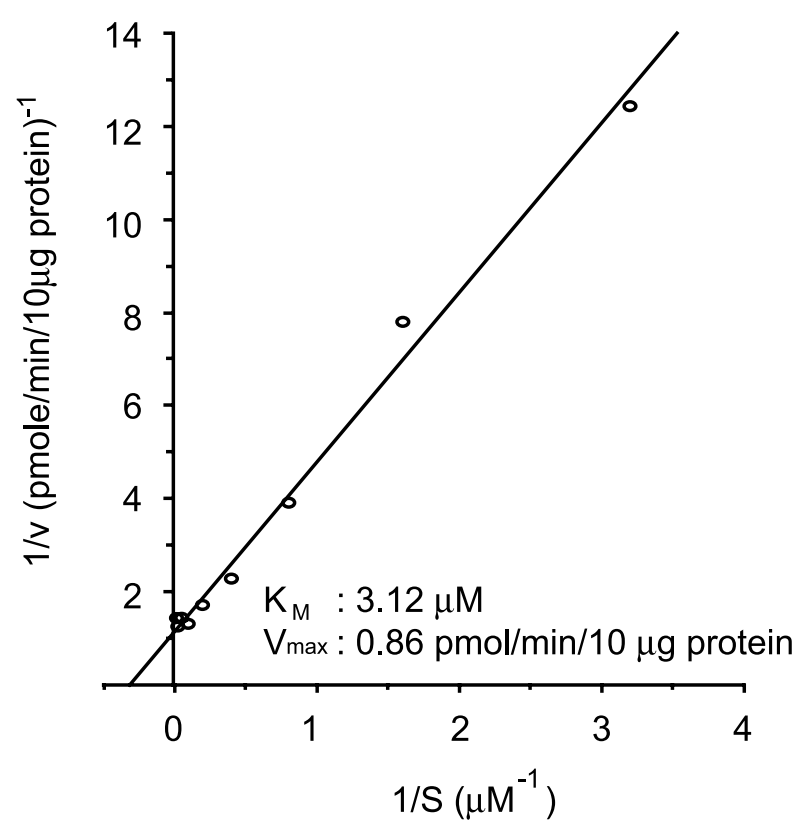

\section{B. $20 \alpha$-DHP in Follicular Fluid}

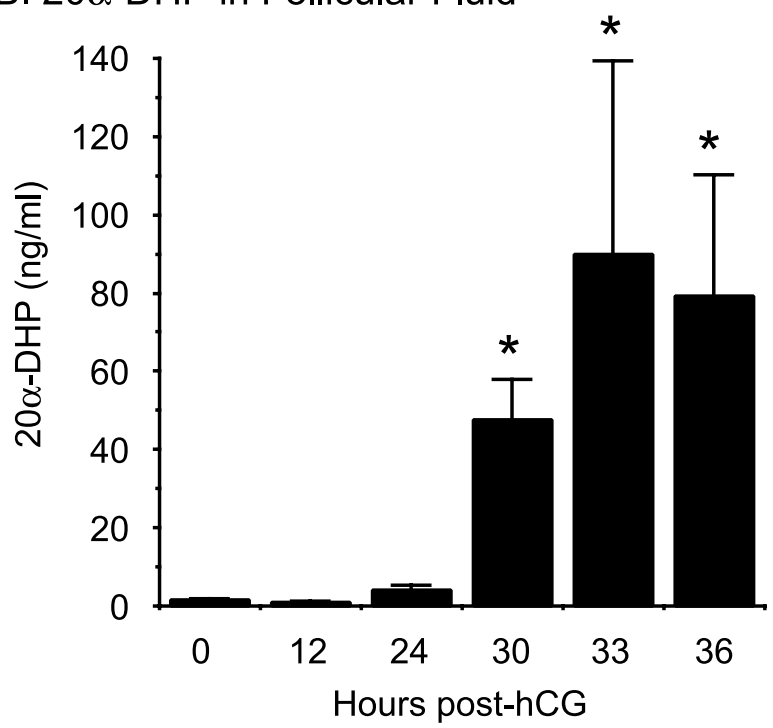

Figure 8 Enzyme kinetics of AKR1C23 and steroid levels in follicular fluid. (A) Lineweaver-Burke plot of $20 \alpha-H S D$ activity of equine AKR1C23. Various concentrations of progesterone were assayed at $37^{\circ} \mathrm{C}$ by monitoring absorbance at $340 \mathrm{~nm}$.

(B) Concentrations of $20 \alpha-$ DHP were measured in follicular fluid of preovulatory follicles isolated between 0 and $36 \mathrm{~h}$ after hCG treatment (mean \pm S.E.M. $n=4-6$ samples per time point (i.e. mares)). Data were transformed to logarithms before analysis as heterogeneity of variance was observed. Bars marked with asterisks are significantly different from $0 \mathrm{~h}$ post-hCG $(P<0.05)$ are intermediates in the gonadotropin-dependent induction of AKR1C23 in follicular cells. The precise physiological significance of AKR1C23 during ovulation and its role in regulating the bioactivity of progestins prior to follicular rupture should also remain the focus of future investigations.

\section{Acknowledgements}

We would like to thank Dr Alain Bélanger and Mr René Bérubé from the Molecular Endocrinology and Oncology Research Centre of the Centre Hospitalier de l'Université Laval (Québec, PG, Canada) for their precious help in measuring the steroid levels in our follicular fluid samples. This study was supported by Natural Sciences and Engineering Research Council of Canada (NSERC) Grant OPG0171135 (to J S), and by a NSERC Postgraduate Scholarship (to K A B), a Canadian Institutes of Health Research (CIHR) fellowship (to D B), and a CIHR Investigator Award (to $\mathrm{JS}$ ), and the authors state that no conflict of interest exists that would prejudice this study's impartiality.

\section{References}

Albarracin CT, Parmer TG, Duan WR, Nelson SE \& Gibori G 1994 Identification of a major prolactin-regulated protein as 20 alpha-hydroxysteroid dehydrogenase: coordinate regulation of its activity, protein content, and messenger ribonucleic acid expression. Endocrinology 134 2453-2460.

Bauminger S, Eckstein B \& Lindner HR 1977 Changes in steroid concentration in the ovaries of immature rats treated with pregnant mare serum gonadotrophin and human chorionic gonadotrophin. Fournal of Endocrinology 75 43-48.

Bérubé R, Malenfant J, Gauvin D, Blais M, Gagnon E, Dumas R, Racine M, Bourque J \& Bélanger A 2000 Quantitation of androgenic and estrogenic steroids in rat and monkey serum using gas chromatography and negative chemical ionization mass spectrometry. ASMS Conference on Mass Spectrometry and Allied Topics, June 11-15, Long Beach, CA.

Blouin K, Blanchette S, Richard C, Dupont P, Luu-The V \& Tchernof A 2005 Expression and activity of steroid aldoketoreductases $1 \mathrm{C}$ in omental adipose tissue are positive correlates of adiposity in women. American Fournal of Physiology. Endocrinology and Metabolism 288 E398-E404.

Boerboom D \& Sirois J 2001 Equine P450 cholesterol side-chain cleavage and 3 beta-hydroxysteroid dehydrogenase/ delta(5)-delta(4) isomerase: molecular cloning and regulation of their messenger ribonucleic acids in equine follicles during the ovulatory process. Biology of Reproduction 64 206-215.

Boerboom D, Kerban A \& Sirois J 1999 Dual regulation of promoter II- and promoter 1 f-derived cytochrome P450 aromatase transcripts in equine granulosa cells during human chorionic gonadotropin-induced ovulation: a novel model for the study of aromatase promoter switching. Endocrinology $1404133-4141$.

Boerboom D, Pilon N, Behdjani R, Silversides DW \& Sirois J 2000 Expression and regulation of transcripts encoding two members of the NR5A nuclear receptor subfamily of orphan nuclear 
receptors, steroidogenic factor- 1 and NR5A2, in equine ovarian cells during the ovulatory process. Endocrinology $1414647-4656$.

Boerboom D, Russell DL, Richards JS \& Sirois J 2003 Regulation of transcripts encoding ADAMTS-1 (a disintegrin and metalloproteinase with thrombospondin-like motifs-1) and progesterone receptor by human chorionic gonadotropin in equine preovulatory follicles. Fournal of Molecular Endocrinology 31 473-485.

Bradford MM 1976 A rapid and sensitive method for the quantitation of microgram quantities of protein utilizing the principle of protein-dye binding. Analytical Biochemistry 72 248-254.

Brûlé S, Rabahi F, Faure R, Beckers JF, Silversides DW \& Lussier JG 2000 Vacuolar system-associated protein-60: a protein characterized from bovine granulosa and luteal cells that is associated with intracellular vesicles and related to human $80 \mathrm{~K}-\mathrm{H}$ and murine beta-glucosidase II. Biology of Reproduction 62 642-654.

Desmond JC, Mountford JC, Drayson MT, Walker EA, Hewison M, Ride JP, Luong QT, Hayden RE, Vanin EF \& Bunce CM 2003 The aldo-keto reductase AKR1C3 is a novel suppressor of cell differentiation that provides a plausible target for the non-cyclooxygenase-dependent antineoplastic actions of nonsteroidal anti-inflammatory drugs. Cancer Research 63 505-512.

el-Kabbani O, Judge K, Ginell SL, Myles DA, DeLucas LJ \& Flynn TG 1995 Structure of porcine aldehyde reductase holoenzyme. Nature Structural Biology 2 687-692.

Filion F, Bouchard N, Goff AK, Lussier JG \& Sirois J 2001 Molecular cloning and induction of bovine prostaglandin E synthase by gonadotropins in ovarian follicles prior to ovulation in vivo. Fournal of Biological Chemistry 276 34323-34330.

Fortune JE 1994 Ovarian follicular growth and development in mammals. Biology of Reproduction 50 225-232.

Frye CA \& Leadbetter EA 1994 5-Alpha-reduced progesterone metabolites are essential in hamster VTA for sexual receptivity. Life Sciences 54 653-659.

Gilles PA \& Karavolas HJ 1981 Effect on ovulation of 20 alpha-hydroxy-4-pregnen-3-one and its 5 alpha-reduced metabolites in immature rats treated with pregnant mare serum gonadotrophin. Fournal of Endocrinology 88 289-292.

Higaki Y, Kamiya T, Usami N, Shintani S, Shiraishi H, Ishikura S, Yamamoto I \& Hara A 2002 Molecular characterization of two monkey dihydrodiol dehydrogenases. Drug Metabolism and Pharmacokinetics 17 348-356.

Hilliard J, Penardi R \& Sawyer CH 1967 A functional role for 20-alpha-hydroxypregn-4-en-3-one in the rabbit. Endocrinology 80 901-909.

Hoog SS, Pawlowski JE, Alzari PM, Penning TM \& Lewis M 1994 Three-dimensional structure of rat liver 3 alpha-hydroxysteroid/ dihydrodiol dehydrogenase: a member of the aldo-keto reductase superfamily. PNAS $912517-2521$.

Hyndman D, Bauman DR, Heredia VV \& Penning TM 2003 The aldo-keto reductase superfamily homepage. Chemico-Biological Interactions 143-144 621-631.

Jez JM, Bennett MJ, Schlegel BP, Lewis M \& Penning TM 1997 Comparative anatomy of the aldo-keto reductase superfamily. Biochemical Journal 326 625-636.

Jornvall H, Persson B, Krook M, Atrian S, Gonzalez-Duarte R, Jeffery J \& Ghosh D 1995 Short-chain dehydrogenases/reductases (SDR). Biochemistry 34 6003-6013.

Kerban A, Boerboom D \& Sirois J 1999 Human chorionic gonadotropin induces an inverse regulation of steroidogenic acute regulatory protein messenger ribonucleic acid in theca interna and granulosa cells of equine preovulatory follicles. Endocrinology $140667-674$.

Lacy WR, Washenick KJ, Cook RG \& Dunbar BS 1993 Molecular cloning and expression of an abundant rabbit ovarian protein with 20 alpha-hydroxysteroid dehydrogenase activity. Molecular Endocrinology 7 58-66.
Lau IF, Saksena SK \& Chang MC 1978 Periovulatory steroid concentrations in HCG-treated rabbits. Hormone Research 9 26-30.

Leyendecker G, Wildt L, Gips H, Nocke W \& Plotz EJ 1976 Experimental studies on the positive feedback effect of progesterone, 17 alpha-hydroxyprogesterone and 20 alpha-dihydroprogesterone on the pituitary release of $\mathrm{LH}$ and FSH in the human female. The estrogen priming of the progesterone feedback on pituitary gonadotropins in the eugonadal woman. Archiv fur Gynakologie 221 29-45.

Lydon JP, DeMayo FJ, Funk CR, Mani SK, Hughes AR, Montgomery CA Jr, Shyamala G, Conneely OM \& O'Malley BW 1995 Mice lacking progesterone receptor exhibit pleiotropic reproductive abnormalities. Genes and Development $92266-2278$.

Madore E, Harvey N, Parent J, Chapdelaine P, Arosh JA \& Fortier MA 2003 An aldose reductase with 20 alpha-hydroxysteroid dehydrogenase activity is most likely the enzyme responsible for the production of prostaglandin $\mathrm{f} 2$ alpha in the bovine endometrium. Journal of Biological Chemistry 278 11205-11212.

Natraj U \& Richards JS 1993 Hormonal regulation, localization, and functional activity of the progesterone receptor in granulosa cells of rat preovulatory follicles. Endocrinology 133 761-769.

Nishizawa M, Nakajima T, Yasuda K, Kanzaki H, Sasaguri Y, Watanabe K \& Ito S 2000 Close kinship of human 20 alpha-hydroxysteroid dehydrogenase gene with three aldo-keto reductase genes. Genes to Cells 5 111-125.

Nordenstrom K \& Johanson C 1985 Steroidogenesis in isolated rat granulosa cells-changes during follicular maturation. Acta Endocrinologica 108 550-556.

Ogle TF \& Beyer BK 1982 Steroid-binding specificity of the progesterone receptor from rat placenta. Foumal of Steroid Biochemistry 16 147-150.

Park JI, Park HJ, Lee YI, Seo YM \& Chun SY 2003 Regulation of NGFI-B expression during the ovulatory process. Molecular and Cellular Endocrinology 202 25-29.

Park OK \& Mayo KE 1991 Transient expression of progesterone receptor messenger RNA in ovarian granulosa cells after the preovulatory luteinizing hormone surge. Molecular Endocrinology 5 967-978.

Pelletier G, Luu-The V, Li S, Ren L \& Labrie F 2003 Sex-related expression of 20 alpha-hydroxysteroid dehydrogenase mRNA in the adult mouse. Fournal of Histochemistry and Cytochemistry 51 1425-1436.

Penning TM, Pawlowski JE, Schlegel BP, Jez JM, Lin HK, Hoog SS, Bennett MJ \& Lewis M 1996 Mammalian 3 alpha-hydroxysteroid dehydrogenases. Steroids 61 508-523.

Penning TM, Burczynski ME, Jez JM, Hung CF, Lin HK, Ma H, Moore M, Palackal N \& Ratnam K 2000 Human 3 alpha-hydroxysteroid dehydrogenase isoforms (AKR1C1AKR1C4) of the aldo-keto reductase superfamily: functional plasticity and tissue distribution reveals roles in the inactivation and formation of male and female sex hormones. Biochemical Journal 351 67-77.

Richards JS 1994 Hormonal control of gene expression in the ovary. Endocrine Reviews 15 725-751.

Ronen-Fuhrmann T, Timberg R, King SR, Hales KH, Hales DB, Stocco DM \& Orly J 1998 Spatio-temporal expression patterns of steroidogenic acute regulatory protein (StAR) during follicular development in the rat ovary. Endocrinology $139303-315$.

SambrookJ, Fritsch EF \& Maniatis T 1989 Molecular Cloning: $a$ Laboratory Manual, edn 2. Cold Spring Harbor Laboratory: Cold Spring Harbor, NY.

Sandhoff TW, Hales DB, Hales KH \& McLean MP 1998 Transcriptional regulation of the rat steroidogenic acute regulatory protein gene by steroidogenic factor 1. Endocrinology $1394820-4831$.

Sirois J \& Doré M 1997 The late induction of prostaglandin G/H synthase-2 in equine preovulatory follicles supports its role as 
a determinant of the ovulatory process. Endocrinology $1384427-4434$.

Stocco CO, Zhong L, Sugimoto Y, Ichikawa A, Lau LF \& Gibori G 2000 Prostaglandin F2 alpha-induced expression of 20 alpha-hydroxysteroid dehydrogenase involves the transcription factor NUR77. Fournal of Biological Chemistry 275 37202-37211.

Strauss JF III \& Stambaugh RL 1974 Induction of 20 alpha-hydroxysteroid dehydrogenase in rat corpora lutea of pregnancy by prostaglandin F-2 alpha. Prostaglandins 5 73-85.

Sugawara T, Kiriakidou M, McAllister JM, Holt JA, Arakane F \& Strauss JF III 1997 Regulation of expression of the steroidogenic acute regulatory protein (StAR) gene: a central role for steroidogenic factor 1. Steroids 62 5-9.

Tang LK \& Spies HG 1975 Effects of gonadal steroids on the basal and LRF-induced gonadotropin secretion by cultures of rat pituitary. Endocrinology 96 349-355.

Watanabe K, Iguchi Y, Iguchi S, Arai Y, Hayaishi O \& Roberts LJ II 1986 Stereospecific conversion of prostaglandin D2 to
(5Z,13E)-(15S)-9 alpha-1 1 beta,15-trihydroxyprosta-5,13-dien-1-oic acid (9 alpha, 11 beta-prostaglandin F2) and of prostaglandin $\mathrm{H} 2$ to prostaglandin $\mathrm{F} 2$ alpha by bovine lung prostaglandin $\mathrm{F}$ synthase. PNAS 83 1583-1587.

Wilson DK, Bohren KM, Gabbay KH \& Quiocho FA 1992 An unlikely sugar substrate site in the $1.65 \AA$ structure of the human aldose reductase holoenzyme implicated in diabetic complications. Science 257 81-84.

Wilson DK, Nakano T, Petrash JM \& Quiocho FA $19951.7 \AA$ structure of FR-1, a fibroblast growth factor-induced member of the aldo-keto reductase family, complexed with coenzyme and inhibitor. Biochemistry 34 14323-14330.

Zhang Y, Dufort I, Rheault P \& Luu-The V 2000 Characterization of a human 20 alpha-hydroxysteroid dehydrogenase. Fournal of Molecular Endocrinology 25 221-228.

Received in final form 30 January 2006 Accepted 27 February 2006 